\title{
Schopenhauer's View on Happiness and Its Practical Significance
}

\author{
Gao Peng \\ School of Humanities \\ Tongji University \\ Shanghai, China 200092
}

\begin{abstract}
As a representative of the school of voluntarism in modern western philosophy, Schopenhauer's philosophy of life is often regarded as pessimistic. However, Schopenhauer has a positive outlook on happiness. This paper mainly adopts the research method of literature analysis, discusses the theoretical source and main content of Schopenhauer's view of happiness, and analyzes its practical significance to people's pursuit of happiness based on the current social reality.
\end{abstract}

Keywords-Schopenhauer; outlook on happiness; practical significance

\section{INTRODUCTION}

Happiness is the goal that people has been striving for all the time. In order to achieve happiness, we must first establish the correct view of happiness. Although Schopenhauer's philosophy of life is often regarded as pessimistic, he has a positive outlook on happiness. His view of happiness is of great practical significance to the pursuit of happiness of the time. In view of this, this paper discusses the theoretical source and main content of Schopenhauer's view of happiness and analyzes its practical significance to people's pursuit of happiness in combination with the current social reality, so as to draw on his view of happiness.

\section{THE THEORETICAL SOURCE OF SCHOPENHAUER'S VIEW ON HAPPINESS}

Schopenhauer's theory of happiness comes from a wide range of sources, including traditional philosophy and religious thoughts. Specifically, its theoretical sources mainly include the following:

\section{A. Ancient Greek and Roman Ethics}

Schopenhauer's view on happiness was greatly influenced by ancient Greek and Roman ethics, especially Aristotle's ethics. In fact, his discussion on the three sources of happiness is largely based on the critical inheritance and creative development of the thoughts on happiness classification in the Nicomachean Ethics. Aristotle divides human happiness into three categories: happiness from the outside, happiness from the mind and happiness from the body. Schopenhauer divides the sources of happiness into the following three categories: Personality, the external things that a person possesses and how others evaluate themselves. ${ }^{[1]}$ In addition, his rules of the pursuit of happiness, so to speak, were inspired by Aristotle. Aristotle points out in his Nicomachean Ethics that "the sages seek not pleasure, but freedom rooted from pain". ${ }^{2]}$ That is to say, what the wise men seek is not pleasure (what is commonly regarded as happiness) but freedom, and specifically freedom from the avoidance and resolution of pain. One of Schopenhauer's rules for the pursuit of happiness was to avoid misfortune as much as possible, which is apparently influenced by Aristotle. In addition, he was also influenced by Plato, the epicurean school, the cynic school, the Ionian school and many other schools of philosophy.

\section{B. Hindu Morality}

Hindu morality mainly advocates abstinence, endurance and fraternity. Schopenhauer pointed out that the obstacle to happiness lies in self-indulgence, and one of the rules of happiness lies in limiting desire with reason. In addition, he points out that another rule of happiness is to know and live in harmony with others. All of this is partly influenced by Hindu morality.

\section{Christian Morality}

Christian morality is mainly starting from the highest human love, leading to abstinence. Schopenhauer proposed that the obstacle to happiness lies in indulgence, and one of the rules of happiness lies in upholding the doctrine of the mean, limiting desire with reason, and having a contented mind. This is partly influenced by Christian morality.

\section{Buddhist Thoughts}

Buddhist thought considers human existence as a kind of "emptiness" or nothingness, while Schopenhauer believes that the essence of life is pain, and life is a pendulum swinging back and forth between the two extremes of pain and boredom. This is partly influenced by Buddhist thought.

\section{THE MAIN CONTENT OF SCHOPENHAUER HAPPINESS VIEW}

The content of Schopenhauer's view of happiness is very rich. Generally speaking, it mainly includes the following aspects: 


\section{A. The Source of Happiness}

From the point of Schopenhauer, the thoughts on the source of happiness mainly include the following:

1) Three sources of happiness and their differences: Schopenhauer believes that happiness comes from three sources: One is what the person is, namely the personality, including health and energy, beauty and talent, moral character, wisdom and education, etc. Second, what man has, namely, wealth and other possible possessions; Third, other people's evaluation on themselves, that is, other people's perception and opinion of themselves, including honor, reputation and identity.

2) Different nature and characteristics of the three major sources of happiness: According to Schopenhauer, the nature and characteristics of the three sources of happiness are different. The first kind of source is absolute, inevitable, invariable, intrinsic, innate, and is the product of nature. The second and third largest sources are relative, contingent, variable, external, acquired, and artificial.

3) Three sources of happiness and their different relationships with happiness: The relationship between these three sources and happiness also varies. The first source is that personality directly determines and affects happiness. All the traits of personality are the most fundamental and direct influencing factors for people's happiness. The second and third sources only affect happiness indirectly.

\section{B. The Characteristics of Happiness}

According to Schopenhauer, the characteristics of happiness mainly include the following:

1) Being temporary: Schopenhauer believed that complete happiness could only be achieved by breaking away from the obstacle of binding volitional behavior. But people can only get out of this barrier temporarily, so happiness is only temporary.[3]

2) Being negative: Schopenhauer points out that all happiness is negative, that our pursuit of happiness is meaningless. It may be more realistic to avoid unhappiness or pain. In addition, the negation of happiness is that it is the negation of pain. In a word, happiness is negative. It is negative itself as well as being negative to pain.

3) Subjectivity: Schopenhauer argues that happiness has a distinct subjectivity. Specifically, its subjectivity is mainly manifested in the following two aspects: first, subjectivity is decisive; second, subjectivity is different. Subject determinacy mainly refers to that the happiness mainly depends on the individual nature. In his view, our happiness depends largely on our nature. In addition, subject difference refers to the fact that different subjects tend to have different happiness in the face of the same environment. He pointed out that happiness embodies a relationship between subject and object. In one experience, the object is the same as the external factor, but the subject or individual's appreciation of it is different from person to person. [4]

4) Ambiguity: In Schopenhauer's view, happiness is vague and often elusive. When we are far from happiness, we will feel its existence and value. When you get close to happiness or have it, you tend to ignore it. Only from a distance can we find where happiness lies, which reflects the ambiguity of happiness

5) Being limited: In Schopenhauer's eyes, happiness is always limited. This depends largely on two reasons: on the one hand, our happiness is limited by our vision, our scope of work, and our vision of the world; on the other hand, the second half of life is more miserable than the first half. As we grow older, our horizons expand and our contacts with the world expand. ${ }^{[5]}$ This makes our happiness more and more limited with the passage of time. Furthermore, the finitude of happiness exists not only in the realm of reality, but also in the realm of thought (the realm of consciousness) In Schopenhauer's view, our pursuit of happiness in the realm of consciousness is also limited. Because the more excited we are, the more likely we are to suffer, the less happy we will be, and the more excited we will be.

\section{Standards of Happiness}

Schopenhauer argues that there are two main criteria for measuring happiness:

1) The degree of relief from pain: Since the essence of happiness lies in avoiding misfortune or pain, one measure of happiness lies in the degree of escaping from pain. But this is an abstract standard, because pain itself is a subjective and uncertain concept. Moreover, it is positively correlated with happiness. That is, the higher the level of escaping from pain, the happier one will be. In short, it's an abstract, positively correlated measure of happiness.

2) Annoying things: That is to say, to judge whether a man is happy or not, one can also look at the things that annoy him. The things that annoy people are generally concrete, sensible, therefore, this is a specific standard. Moreover, it is negatively correlated with happiness. In other words, the more trivial the things that upset someone, the happier they are in some aspects. Because poor people or people who are not rich have absolutely no spare time or energy to pay attention to the minutiae of life, they have to struggle under the pressure of real life. All in all, this is a specific, negatively correlated standard.

\section{The Highest Goal of Happiness}

Schopenhauer believes that the highest goal of happiness is inner peace and happiness. Inner peace and happiness are in themselves a kind of happiness, which can effectively compensate for the deficiencies caused by the absence of all other kinds of happiness. Therefore, the highest goal of happiness is inner peace and happiness. 


\section{E. The Enemy of Happiness}

Schopenhauer points out that happiness has two enemies: misery and boredom. In his view, if we are lucky enough to be free of pain, we are close to boredom; if we are away from boredom we are close to pain. So, in a way, one's life is like a pendulum, swinging back and forth wildly between the ends of pain and boredom.

\section{F. Obstacles to Happiness}

According to Schopenhauer, self-indulgence is the greatest obstacle to happiness. This is because: it increases our pain and also may increase our boredom. Self-indulgence faces no more than two possible outcomes: 1 . When desire is satisfied, it will lead to boredom. 2. Unsatisfied desire brings pain. And boredom and misery are the two great enemies of happiness, that is to say, self-indulgence strengthens the enemies of happiness, and further distances us from it.

\section{G. Rules for the Pursuit of Happiness}

In Schopenhauer's view, we must also follow a series of rules in the pursuit of happiness. These rules mainly include the following:

1) Knowing yourself, transcending and improving yourself: According to Schopenhauer, the prerequisite for our pursuit of happiness is to know ourselves. To understand oneself mainly includes the following two aspects: One is to know your specific goals. These goals include understanding your character and abilities, your responsibilities and obligations, and your relationship to the world. The second is to know one's correct method. In Schopenhauer's view, to understand ourselves, we must look at our life through all the stages of our lives and see it through the lens of connection and development. To surpass and improve oneself is mainly to improve one's personality, enrich one's heart, improve one's mind (mind management ability) and other various abilities.

2) Getting to know other people and living in harmony with them: Schopenhauer believes that one should always be ready to do and can do the following two things in his life journey: be proactive and open-minded. The former keeps him from loss and injury while the latter keeps him from conflict and argument. ${ }^{[6]}$ Prevention in advance means that in the process of interacting with others, we should know how to maintain proper distance and self-protection from others. Open-mindedness means to be tolerant with others in the process of communication. In a word, the essence of the above contents is to understand others and learn to live in harmony with others.

3) Trying to avoid misfortune: Schopenhauer believes that we should not aim for the comfort and pleasure of our lives but try to avoid the misfortunes of our lives. Living happily simply means living less unhappily. ${ }^{[7]}$ That is to say, we should not regard happiness as a goal to pursue but should avoid misfortune to approach real happiness.
4) Following the doctrine of the mean: The doctrine of the mean is easy to say, but actually contains rich connotation and implication. Specifically, the following two points should be well followed:

a) using rationality to limit desire and being content: Schopenhauer believes that we also need to reasonably limit our desires for happiness. He pointed out that the most effective way to avoid falling into too miserable a life is not to expect too much from happiness. In other words, limit your desire for happiness and be content.

b) To maintain a proper proportion between the present and the future and to live in the present: Another important factor in rational behavior, Schopenhauer points out, is maintaining an appropriate ratio between the present and the future.[8] In other words, we should live in the present and maintain an appropriate proportion between the present and the future.

\section{The PRACTICAL SignificANCE OF SCHOPENHAUER'S HAPPINESS VIEW}

Schopenhauer's view of happiness is of great practical significance to people's pursuit of happiness. Specifically, its practical significance mainly includes the following:

\section{A. To Know and Surpass Oneself, and to Be the Best One}

The immediate and fundamental source of happiness lies in one's personality. Therefore, everyone should constantly improve their own realm of personality. The premise of being the best version of yourself is to know who you are. In order to understand ourselves, we need to focus on the whole life, and use the holistic and historical perspective to examine and analyze all the life stages we have experienced. The goal of knowing yourself is to understand your own abilities and inadequacies, recognize your responsibilities, and see your general relationship with the world. Then, based on the reality of the ego we can determine some of the appropriate goals. Finally, continue to transcend and improve yourself in accordance with these goals.

\section{B. To Be Kind to Others and to Live in Harmony with Others}

Man is a social animal, and everyone can't avoid interacting with others. As a component of the external objective environment constituting by individuals, others will exert a certain influence on the individual's happiness. Therefore, in the pursuit of happiness, everyone also needs to be kind to others and live in harmony with others.

\section{To Cherish the Present Happiness and Avoid Misfortune and Pain}

Happiness is relative, temporary, vague and limited. Therefore, in life, when we are happy, we should cherish this temporary happiness, and should not regret until we lost it. On the other hand, when we encounter misfortune, we should seek happiness from bitterness and avoid wallowing in misery and misfortune. In fact, misfortune is more of a normal state of life. As the saying goes, there are unhappy 
things in lives for nine times out of ten. In a word, we should cherish happiness and try to avoid misfortune and pain.

\section{To Stick to the Mean of Doctrine and to Keep the Balance and Harmony of Life}

According to Schopenhauer's view of happiness, in order to pursue happiness, we must adhere to the doctrine of the mean and maintain the balance and harmony of life. Specifically, we should do the following two points:

1) To keep a good attitude and to be content: Selfindulgence is the greatest barrier to happiness. Therefore, in real life, we need to use reason to limit our desires to a moderate and reasonable range, so as to maintain inner peace and happiness and contentment.

2) To live in the present and to take a view at the future: We need to find a balance between the present and the future. We should both live in the present and take a view at the future. We should also keep our heads down to keep working hard in pursuit of happiness. We should also keep our head up and make sure our direction is right.

\section{CONCLUSION}

To sum up, Schopenhauer's happiness view is more realistic. This realism is reflected in his in-depth analysis of the issue of happiness which is close to reality. Therefore, till today, his concept of happiness is still very important to people's thinking and pursuit of happiness. These practical implications can be concluded to one central point, which is that happiness is primarily about oneself. To achieve happiness, we need to understand and transcend ourselves, be kind to others, cherish our present happiness, and keep a balance between reality and future. And to achieve these, it mainly depends on one's own thought and action. In short, to be happy, we should start with your thoughts and actions. We should correct our thoughts before act.

\section{REFERENCES}

[1] Schopenhauer, translated by Li Chengming, et al. Schopenhauer Philosophy of life [M]. Beijing: Jiuzhou Press, July 2003, page 1.

[2] Schopenhauer, translated by Li Chengming, et al. Schopenhauer philosophy of life [M]. Beijing: Jiuzhou Press, July 2003, page 106.

[3] Schopenhauer, translated by Li Chengming, et al. Schopenhauer philosophy of life [M]. Beijing: Jiuzhou Press, July 2003, page 107.

[4] Schopenhauer, translated by Li Chengming, et al. Schopenhauer philosophy of life [M]. Beijing: Jiuzhou Press, July 2003, page 3.

[5] Schopenhauer, translated by Li Chengming, et al. Schopenhauer philosophy of life [M]. Beijing: Jiuzhou Press, July 2003, page 123124.

[6] Schopenhauer, translated by Li Chengming, et al. Schopenhauer philosophy of life [M]. Beijing: Jiuzhou Press, July 2003, page 164.

[7] Schopenhauer, translated by Li Chengming, et al. Schopenhauer philosophy of life [M]. Beijing: Jiuzhou Press, July 2003, page 107108.

[8] Schopenhauer, translated by Li Chengming, et al. Schopenhauer philosophy of life [M]. Beijing: Jiuzhou Press, July 2003, page 61. 